\title{
EPIDEMIOLOGY AND RECURRENCE RATE OF PTERYGIUM POST EXCISION IN GHANAIANS
}

\author{
V.A. ESSUMAN ${ }^{1}$, C.T. NTIM-AMPONSAH ${ }^{1 A}$, G. K. VEMUGANTI ${ }^{2}$ and T. A. NDANU ${ }^{3}$ \\ ${ }^{1}$ Ophthalmology Unit, Department of Surgery, University of Ghana Medical School, Ghana, ${ }^{2}$ Ophthalmic \\ Pathology Service, LV Prasad Eye Institute, Hyderabad, India, ${ }^{3}$ University of Ghana Dental School, College \\ of Health Sciences, University of Ghana. ${ }^{1 \mathrm{~A}}$ Deceased
}

DOI: http://dx.doi.org/10.4314/gmj.v48i1.6

Corresponding Author: Dr. V.A. Essuman

Email: vadessuman@yahoo.com

Conflict of Interest: None declared

\section{SUMMARY}

Objectives: To determine the epidemiology and recurrence rate of pterygium after excision using bare sclera technique

Design: Prospective non-comparative study.

Setting: Ophthalmology unit, Korle-Bu Teaching Hospital, Accra, Ghana.

Methods: The study involved 60 consecutive patients with primary apterygial from July 1998 to December 2000 who had bare sclera excision after informed consent. They were post-operatively followed up for 30months.

Results: Thirty-five patients (58\%) were females. The patients' ages ranged from 17-75 years, mean $( \pm 12.6)$. Overall recurrence was $22(37 \%)$. The main complications encountered include were granuloma $20 \%$ ( $\mathrm{n}=12)$, restriction in medial rectus muscle motility $2(3 \%)$, persistent vascularisation at excision site $2(3 \%)$ and adherence leucoma with uveitis 1(2\%). No significant association was found between recurrence and pterygium morphology, calcification, allergy and occupation (indoor or outdoor).

Conclusion: The recurrence rate after pterygium excision using bare sclera technique in Ghanaians is high (37\%).

Keywords: Pterygium, epidemiology, bare sclera excision, recurrence, conjunctival growth.

\section{INTRODUCTION}

Pterygium is a benign fibrovascular growth which invades the cornea from the conjunctiva and is common in the tropics. It is associated with ultraviolet light and also dusty environment. ${ }^{[1,2]}$ It often gives rise to irritation, redness and eye discomfort and is cosmetically unsightly. Treatment is surgical but high recurrence rates are primarily seen after bare sclera surgery, 24$>80 \%,{ }^{[3,4,5,6]}$ and remains a problem. Different adjuvants to bare sclera surgery have been tried all aiming at reducing the recurrence. These include B-radiation with Strontium-90, chemotherapeutic agents such as mitomycin- $\mathrm{C}$ and conjunctival autograft. ${ }^{7-10}$

At the time of this study, the surgical procedure commonly performed was excision using bare sclera technique. Anecdotal observation has shown both successes and recurrences after long-term follow up in years. Over the years, some ophthalmologists have modified their practice with a gradual shift towards the use of adjuvants to bare sclera surgery such as mitomycin-C and conjunctival autograft.

There are still some ophthalmologists who perform bare sclera excision alone in Ghana. The study therefore aimed at determining the epidemiology of primary pterygium and recurrence rate after excision using bare sclera technique in Ghanaians.

\section{METHODS}

Sixty consecutive patients with primary pterygia who had bare sclera excision after informed consent at the Ophthalmology unit, Korle-Bu Teaching Hospital, Ghana, from July 1998 to December 2000 were studied. They were post-operatively followed up for 30months.

A structured questionnaire was used to collect information on the patients' occupation (outdoor or indoor), use of spectacles, history of allergy or atopy, and any other ocular disease. In addition, clinical examination noted the morphology of the pterygia (fleshy/vascularised, intermediate, or atrophic) based on the translucency of the pterygia and presence or absence of calcification, its laterality (unilateral or bilateral), location (nasal, temporal or kissing), its extent into cornea and encroachment on the visual axis.

\section{Data analysis}

Time of recurrence in months was summarized as means and standard deviation. Chi-square test was used to compare the proportions of various categories of 
conditions. Logistic regression was employed to establish causal associations between various risk factors. Significance was set at alpha $=0.05$

\section{RESULTS}

Demographics: Thirty-five patients (58\%) were females. The patients' ages ranged from 17-75 years, mean $( \pm 12.6)$.

Laterality: $37(62 \%)$ were bilateral; $13(21.7 \%)$ were left and $10(16.7 \%)$ were right.

Orientation: $57(95.0 \%)$ were nasal; $1(1.7 \%)$ temporal and $2(3.3 \%)$ kissing (both nasal and temporal in the affected eye).

Calcification: 20 out of $60(33 \%)$ demonstrated presence of calcifications.

Morphology: 7(12\%) were transparent/ atrophic (T1); $41(68 \%)$ were intermediate (T2) and 12(20\%) were vascularised / fleshy (T3).

Allergy: Nineteen out of sixty (32\%) admitted to having allergy to dust, $17 / 60(28 \%)$ to perfume and $11(18 \%)$ to history of asthma.

Recurrence: The overall recurrence was 22(37\%). The mean time of recurrence was $4.27( \pm 2.03)$ months. The recurrence time showed a bimodal pattern at 3months: $10(45 \%)$ and at 6 months: $7(32 \%)$.

Complications: The main complications encountered were granuloma $20 \%(\mathrm{n}=12)$, restriction in medial rectus muscle motility $2(3 \%)$, persistent vascularisation at excision site $2(3 \%)$ and adherence leucoma with uveitis $1(2 \%)$. No significant association was found between recurrence and pterygium morphology, presence of calcification, allergy and occupation (indoor or outdoor).

\section{DISCUSSION}

This study provides basic epidemiological and clinical features of pterygium, a common eye disease in warm climates. The overall recurrence was high, 37\%. This high recurrence rate corroborates other findings associated with bare-sclera technique alone as a method of treatment of pterygium, compared with other forms of surgical or adjuvant treatments. $5-16$

The risk factors for recurrence include geographic location $^{17}$, age ${ }^{15}$, morphology and fleshiness or vascularity of pterygium $^{15}$ and other factors such as allergy or immunological factors. ${ }^{18-20}$ This study did not demonstrate any significant association between recurrence and vascularity (atrophic, vascularised), allergy to dust, allergy to perfumes and spray, history of asthma, or type of occupation (indoor or outdoor) and gender.

Majority of the recurrences were observed in the first year post excision with a bimodal presentation with peaks at 3 and 6 months. This pattern of recurrence is corroborated by Hirst et al who also found a $97 \%$ chance of recurrence within 12 months of the removal without the bimodal component. ${ }^{21}$

The bimodal pattern of recurrence observed was unexpected. This finding has not been highlighted in the literature.

Table 1 Relationship between recurrence and risk factors for pterygium.

\begin{tabular}{|l|l|l|l|}
\hline Characteristics & Recurrence & $\begin{array}{l}\text { No Recur- } \\
\text { rence }\end{array}$ & p-value \\
\hline $\begin{array}{l}\text { Gender } \\
\text { Female } \\
\text { Male }\end{array}$ & 11 & 24 & \\
\hline $\begin{array}{l}\text { Calcification } \\
\quad \text { Yes }\end{array} \quad$ No & 6 & 14 & 0.417 \\
\hline $\begin{array}{l}\text { Vascularity } \\
\text { Atrophic }\end{array}$ & 16 & 14 & 0.573 \\
Vascularized & 21 & 24 & \\
\hline $\begin{array}{l}\text { Allergy to Dust } \\
\text { Yes }\end{array}$ & 4 & 6 & 0.06 \\
No & 18 & 32 & 0.147 \\
\hline $\begin{array}{l}\text { Asthma } \\
\text { Yes }\end{array}$ & 3 & 15 & \\
No & 19 & 23 & 0.731 \\
\hline $\begin{array}{l}\text { Perfume } \\
\text { Yes }\end{array}$ & 4 & 8 & 0.241 \\
No & 18 & 30 & \\
\hline $\begin{array}{l}\text { Occupation } \\
\text { Indoors }\end{array}$ & 13 & 13 & \\
Outdoors & 8 & 25 & \\
\hline
\end{tabular}

Further studies in the Ghanaian population using larger series are needed to establish whether this pattern of recurrence was an incidental finding or something peculiar to our population. There was no gender difference with respect to pterygium occurrence; male: female ratio was 5:7. In the literature, there had been conflicting reports on the male to female ratio in patients with pterygium. Whereas some report male preponderance as in Southern India ${ }^{11,20,21}$ others show female preponderance as in Ibadan in Nigeria where the male: female ratio was found to be $5: 6 .^{5}$

However, the difference in this study was not statistically significant. The difference is sometimes thought to be due to more exposure to environmental factors in the males as a result of their mostly outdoor occupation. Places where the females work outdoors as frequently as their male counterparts, as may be found in urban areas in Africa like Ibadan and Accra, ${ }^{5}$ there may be no gender difference or even a female preponder- 
ance. The latter may also be due to females being more cosmetically conscious of the growth.

The age range affected was $17-75$ years with a mean age of 45.6 years. This compares with other studies on prevalence of pterygium where it occurs about the second decade with the highest prevalence in the $4^{\text {th }}$ and $5^{\text {th }}$ decades. ${ }^{5,14,22,23}$ A few occurrences have been seen in the $1^{\text {st }}$ decade though. ${ }^{14,24}$

The commonest presentation was bilateral in $61.7 \%$. This supports findings from the West African subregion where Ashaye found $71 \%$ of his patients to have bilateral presentation, ${ }^{5}$ but this contradicts the findings from India where Fernandes M. et al found only $7.5 \%$ of the patients to have bilateral pterygia. ${ }^{14}$ Ibechukwu in Jos, Nigeria, found the occurrence of pterygium on the right side to be commoner than the left with a ratio of $1.3: 1^{13}$ a finding also observed by Hirst et. al. ${ }^{21}$

The lesion was found on the nasal side predominantly $(95 \%)$ and hardly on the temporal side $(2 \%)$ or both nasal and temporal (kissing or double pterygia) (3\%). This corroborates findings from other studies. ${ }^{5,13}$ It is not clear the reason for this occurrence.

Calcifications were found in a third of the lesions and most were vascularised i.e. intermediate and fleshy $(88 \%)$. Very few atrophic ones were seen $(12 \%)$ as reported in other studies. $5,14,16$

Only $32 \%$ of our study population had a history of allergy (to dust, perfumes, sprays and drugs). The prevalence of allergy in Ghana is unknown. No significant association was found between allergy or asthma and pterygium recurrence. This observation may be due to the small numbers that reported a history of allergy, atopy or asthma, which could also be attributed to the difficulty encountered in obtaining such history from this population. ${ }^{25}$

Granulomas are recognised minor post-operative complications seen with bare sclera technique, and other serious complications such as medial rectus restriction are also known complications. ${ }^{16}$

\section{CONCLUSION}

The recurrence rate after pterygium excision using bare sclera technique in Ghanaians is high $(37 \%)$. This study is the first to determine the recurrence rate of pterygium excision with bare sclera technique in Ghanaians and provides important and relevant information for ophthalmic practice in Ghana. This finding should discourage the use of this technique alone by ophthalmic surgeons in Ghana as in other parts of the world.
The finding would also form the basis for comparison for any future studies in Ghana which would aim at reducing recurrence.

\section{REFERENCES}

1. Strzhizhovskiı AD. The biomedical effects of ultraviolet radiation and their mechanisms. Usp Fiziol Nauk. 1995; 26:98-112.

2. Sekelj S, Dekaris I, Kondza-Krstonijević E, et.al. Ultraviolet light and pterygium. Coll Antropol. 2007; 31 Suppl 1:45-7.

3. Sebban A, Hirst LW. Treatment of pterygia in Queensland. Aust NZ J Ophthalmol 1991; 19: 1237.

4. Jaros PA, DeLuise VP. Pingueculae and pterygia. Surv Ophthalmol 1988; 33: 41-9.

5. Ashaye A.O. Pterygium in Ibadan. West African Journal of Medicine, 1991;10: 232-243.

6. Retty I., Fregene A.O, Salomon K. Post operative Beta irradiation of pterygium. Nig. Med. J 1973;3: 196-197.

7. Walter WL: Another look at pterygium surgery with postoperative beta radiation. Ophthal Plast Reconstr Surg 10:247-52, 1994.

8. Gris O, Guell JL, del Campo Z: Limbalconjunctival autograft transplantation for the treatment of recurrent pterygium. Ophthalmology. 2000 107:270-3.

9. Mahar PS,Nwokora GE. Role of mitomycin C in pterygium surgery. Br J Ophthalmol 1993;77:4335.

10. Lewallen S. A randomized trial of conjunctival autografting for pterygium in the tropics. Ophthalmology 1989;96:1612-4.

11. MacKenzie FD, Hirst LW, Kynaston B, et al: Recurrence rate and complications after beta irradiation for pterygia. Ophthalmology 1991; 98:177680.

12. Hsiao $\mathrm{CH}$, Chen JJ, Huang SC, et al: Intrascleral dissemination of infectious scleritis following pterygium excision. $\mathrm{Br} J$ Ophthalmol. 82:29-34, 1998.

13. Ibechukwu B.I. Post-operative Management of Pterygium in Jos, Nigeria- comparison of antibiotics, steroids and opticrom. East African Med J. 1992: 69; 490- 493.

14. Fernandes M, Sangwan VS, Bansal AK, et al. Outcome of pterygium surgery: analysis over 14 years. Eye 2005; 19, 1182-1190.

15. Tan DTH, Chee SP, Dear KBG, et al. Effect of pterygium morphology on pterygium recurrence in a controlled trial comparing conjunctival autografting with bare sclera. Arch 1997; 115: 12351240 .

16. Hirst LW. The treatment of pterygium. Surv Ophthalmol. 2003; 45: 145-180. 
17. Doughman DJ. In discussion: Kenyon KR, Wagoner MD, Hettinger ME. Conjunctival autograft transplantation for advanced and recurrent pterygium. Ophthalmology 1985; 92: 1470

18. Butrus S I, Ashraf M.F, Laby DM, et al. Increased numbers of mast cells in pterygia. Am J Ophthalmol. 1995; 119:236-7.

19. Nakagami T, Murakami A, Okisaka S, et al. Mast cells in pterygium: number and phenotype. Jpn J Ophthalmol. 1999;43:75-9.

20. Pinkerton O. D, Hokama Y, Shigemura L.A. Immunologic basis for the pathogenesis of pterygium. Am J Ophthalmol. 1984; 98:225-8.
21. Hirst L. W, Sebban A, Chant D. Pterygium Recurrence Time. Ophthalmology. 1994; 101: 755-758.

22. Dimitry $\mathrm{T} J$. The dust factor in the production of pterygium. Am. J. Ophthal.1937;20; 40-44.

23. Duke Elder S (1965): System of Ophthalmology Vol.VIII part I Henry Kimptom London.

24. Bloom AH, Perry HD, Donnenfeld ED, et al. Childhood onset of pterygia in twins. Eye Contact Lens. 2005 Nov; 31(6):279-80.

25. Ntim-Amponsah CT, Quarcoopome CO, Dickson KB. Vernal Kerato-Conjunctivitis- characteristics seen in Ghanaians. Asia-Pacific Journal of Ophthalmology. 1997; 9:10-13. 